\title{
American Geriatrics Society identifies five things that healthcare providers and patients should question
}

\section{AGS Choosing Wisely Workgroup}

Thanks to pharmaceutical and surgical breakthroughs, the development of vaccinations against once-devastating infectious diseases, and greatly improved sanitation, Americans are living far longer than their predecessors just a few generations ago. Adults turning 65 this year can expect to live, on average, another 19 years. ${ }^{1}$

For a significant part of their later years, however, many older Americans are living with serious health problems. Many have more than one. More than half of all adults 65 and older in the United States have three or more chronic diseases, thereby meeting the criteria for multimorbidity. ${ }^{2}$

Treating older patients can be challenging. Due to age-related anatomical and physiological changes, older adults may respond differently to medications and procedures than younger patients. Because older adults -- particularly older adults with multiple disorders -- are underrepresented in clinical trials, judging the appropriateness of treatments for aging patients can be difficult. ${ }^{3}$

Further complicating care for the more than 50 percent of older patients with multimorbidity, current clinical practice guidelines tend to focus on the treatment of individual disorders and, consequently, may not be applicable to those with multiple disorders. According to a seminal 2005 study, following all of the individual clinical guidelines applicable to a hypothetical, 71-year-old woman with chronic obstructive pulmonary disease, type 2 diabetes, osteoporosis, hypertension, and osteoarthritis would

\footnotetext{
Address correspondence to Mary Jordan Samuel, American Geriatrics Society, 40 Fulton Street, 18th Floor, New York, NY 10038. mjsamuel@americangeriatrics.org.

Paul Mulhausen, MD, vice-chair of the society's Clinical Practice and Models of Care Committee headed the society's Choosing Wisely Workgroup. Workgroup members included Audrey Chun, MD; Ariel Green, MD, MPH; Arthur Hayward, MD; Sei Lee, MD, MCR; Bruce Leff, MD, AGSF; Matthew McNabney, MD; Pushpendra Sharma, MD, CMD; and Caroline Vitale, MD, AGSF. In addition, the society sought guidance from an advisory group composed of Rosanne Leipzig, MD; Sharon Levine, MD; and David Reuben, MD, and consulted with this group throughout the process. Additional content experts who were consulted on specific recommendations included Nicki Brandt, PharmD, CGP, BCPP; Thomas Finucane, MD; Sunny Linnebur, PharmD, FCCP, BCPS, CGP; Carol M. Mangione, MD, MSPH; Gerardo Moreno, MD; James Pacala, MD, MS, AGSF; Debra Saliba, MD, MPH, AGSF; and Joseph Shega, MD.
}

AUTHORS AND CONTRIBUTORS The society's Choosing Wisely Workgroup was headed by Paul Mulhausen, MD, vice-chair of the society's Clinical Practice and Models of Care Committee. Workgroup members included Audrey Chun, MD; Ariel Green, MD; Arthur Hayward, MD; Sei Lee, MD, MCR; Bruce Leff, MD, AGSF; Matthew McNabney, MD; Pushpendra Sharma, MD, CMD; and Caroline Vitale, MD, AGSF. In addition, the society convened an advisory board including Roseanne Leipzig, MD, Sharon Levine, MD, and David Reuben, MD, and consulted with this group throughout the process. Additional content experts included in the process were Thomas Finucane, MD; Joseph Shega, MD; Debra Saliba, MD, MPH, AGSF; Gerardo Moreno, MD; Sunny Linnebur, PharmD, FCCP, BCPS, CGP; Nicki Brandt, PharmD, CGP, BCPP; and Jeff Halter MD.

CONFLICTS OF INTEREST Drs. Green, McNabney, Mulhausen, Sharma and Vitale indicated no conflicts of interest. Dr. Chun is a Janssen Immunotherapy Research \& Development consultant for Alzheimer's disease advisory Board Medical Home Model. Dr. Hayward is a paid consultant for Kaiser Permanent. Dr. Lee has financial interests in the following: Mylan, Inc., USG Corporation, Infosys Ltd, Bank of America Corp, Aluminum Corp. of China Limited, Posco, Leucadia National Corp, Berkshire Hathaway Inc., Guangshen Railway Co. Ltd, ABH. Dr. Leff is a paid consultant for Amedisys Corporation and has received grants through AHRQ/ NIA on Guided Care, Hartford Foundation on Hospital at Home and Atlantic Philanthropies on geriatric service models. Dr. Leff is paid to serve on a test writing committee for the American Board of Internal Medicine 
result in her taking a list of medications that would put her at significant risk of multiple drug side effects, and drug-drug interactions. ${ }^{4}$

Concerns about inappropriate care for older adults are not limited to the overprescribing of medications. In the April 2012 issue of the Journal of the American Medical Association, Donald M. Berwick, MD, former Administrator of the Centers for Medicare and Medicaid Services (CMS), and Andrew D. Hackbarth, MPhi, also highlight the overuse of surgery and "unwanted intensive care at the end of life for patients who prefer hospice and home care." With the eldest of the US's 77 million "Baby Boomers" already 65, addressing inappropriate treatment for older patients is imperative.

Established in 1938, the American Geriatrics Society (AGS) is a non-profit organization of more than 6,000 health professionals dedicated to improving the health, independence, and quality of life of older people. Enhancing healthcare for all older patients - including those with complex and multiple disorders - and working to ensure that their care is both appropriate and in keeping with their wishes, is central to AGS' mission. To accomplish this mission, the society provides information and leadership to healthcare professionals, policy makers, and the public; and advocates for and implements programs in healthcare, research, public policy, and professional and public education.

In a recent initiative to improve prescribing for older patients, the AGS both updated and expanded the Beers Criteria for Potentially Inappropriate Medication Use - one of the most frequently consulted sources of information about safe prescribing for older patients. The society convened a multidisciplinary expert panel that revised, expanded, and enhanced the criteria based on a systematic literature review and evaluation of the evidence base.

Renamed the 2012 AGS Beers Criteria for Potentially Inappropriate Medication Use, it was published in The Journal of the American Geriatrics Society (JAGS) in early 2012. ${ }^{3}$ At the same time, the society's Foundation for Health in Aging (FHA) published a series of easily understood articles for laypeople based on the new criteria. The articles explain how older adults and their caregivers can lessen risks of adverse drug events and drug-drug interactions. They are available on the society's public education website, www.healthinaging.org/.

The AGS launched another major initiative later in 2012 -- this focusing exclusively on improving care for multimorbid older patients- and convened an expert panel to undertake it. Older adults with multimorbidity run a particularly high risk of treatment side effects and interactions, as well as disability, institutionalization, and death.

The panel developed a series of guiding principles for the care of these older adults, principles outlining a management approach that clinicians can follow to provide these patients with more appropriate, individualized care. The approach considers a range of issues particular to each patient's care. These include not only the limited evidence base, but also: interactions among conditions and among treatments; the patient's preferences and goals and the varying prognoses associated with these; the probable presence of multifactorial geriatric syndromes among these older adults; and the feasibility of each management decision and its implementation. In addition to outlining this approach to caring for these patients, the panelists also called for the development of sufficient evidence to, eventually, serve as the basis for an actual guideline. The panel published two documents -- a comprehensive background document and a summary report -- in the April 2012 issue of $J A G S$. As it did following the publication of the 2012 AGS Updated Beers Criteria, the AGS Foundation published comprehensive public education materials regarding the unique needs of multimorbid older adults, and how following the guiding principles can help improve their care. 
Given the society's commitment to improving healthcare for older adults by, among other things, educating older people and their caregivers about their health and healthcare choices, the AGS was delighted to be invited to take part in the American Board of International Medicine (ABIM) Foundation's "Choosing Wisely ()" campaign. In November of 2011, the ABIM asked the society to join this important initiative.

"Choosing Wisely" is designed to engage patients, their healthcare professionals, and their family caregivers in discussions about the safety and appropriateness of medical tests, medications, and procedures. Ideally, these discussions should examine whether the tests and procedures are evidence-based; whether any risks they pose may overshadow their potential benefits; whether they are redundant; and whether they are truly necessary. In addition to improving the quality of care, the initiative aims to rein in unneeded healthcare spending. According to a 2008 Congressional Budget Office report, as much as 30 percent of healthcare spending in the U.S. may be unnecessary. ${ }^{6}$

The ABIM launched the "Choosing Wisely ®" campaign in 2011 with an initial group of nine U.S. medical societies. It asked each of the nine to identify five medical tests, medications, or procedures that physicians and patients should question. Lists of the tests, medications, and procedures that the nine organizations identified as warranting scrutiny and discussion are posted on the initiative's website, choosingwisely.org So is easily understood information, translated into laymen's terms, that Consumer Reports has developed for patients and their family caregivers.

The American Geriatrics Society was among the second group of medical organizations asked to join the initiative. After a review of the evidence, and careful deliberation among the AGS's experts, the society identified five commonly prescribed medications and treatments that older patients and their healthcare providers and family caregivers should question and discuss.

The society's list of "five things," listed below, is intended to help facilitate discussions, between older adults and their healthcare providers, regarding the appropriateness of treatment options. The list is not intended to take the place of healthcare professionals' judgment, or substitute for a consultation with a healthcare provider.

\section{METHODS}

The ABIM asked each participating organization to identify five tests, medications, or treatments commonly used in their specialty for which there is currently insufficient evidence of safety or appropriateness, and that may pose risks for patients that outweigh potential benefits.

Each organization was allowed to determine how to identify its "five things" as long as the following criteria were met:

- each of the five were within the specialty's purview - that is, were among those tests or procedures the society's members perform,

- the tests and procedures were frequently utilized in the specialty or were costly,

- each recommendation was based on sufficient evidence and

- the process for making the decisions was documented and would be made available to the public if requested.

In April of 2012, the AGS started work on its list, convening a Choosing Wisely Workgroup headed by Paul Mulhausen, MD, vice-chair of the AGS' Clinical Practice and Models of 
Care Committee. To ensure that potential conflicts of interest are disclosed and addressed appropriately, workgroup members disclosed potential conflicts of interest at the beginning of the process. Each workgroup member's potential conflict of interest are provided at the end of this document.

After conducting preliminary research focused on tests and treatments commonly recommended for older adults, the workgroup surveyed the society's members via its website (www.americangeriatrics.org) and weekly list serv, asking them what tests and procedures should be included in the list. The AGS then expanded the survey to others in the field via the Association of Directors of Geriatrics Academic Programs list serv (http:// adgap.americangeriatrics.org) the GeriPal blog (www.geripal.org), and the POGOe website (www.pogoe.org). All told, the society received more than 300 individual responses to the survey. The workgroup reviewed this list, and identified the tests or treatments most recommended for inclusion in the list, narrowing the number of tests and procedures to ten. Workgroup members then consulted with AGS members with expertise in these areas, discussing current research, clinical experience and opinions on each. Based on these reviews, and on expert opinions, members of the workgroup identified the final five "things," and worked on finalizing the list.

The list of AGS' five has been posted on both the ABIM's website, www.choosewisely.org, and linked to from the AGS' wesbites www.americangeriatrics.org and www.healthinaging.org. As part of this the AGS and the AGS Foundation have developed and published a series of online professional and public resources on the society's "five things".

\section{RESULTS}

\section{The American Geriatrics Society's List of Five Things Physicians and Patients Should Question}

\section{Don't recommend percutaneous feeding tubes in patients with advanced dementia; instead, offer assisted oral feeding-Careful hand feeding of patients} with severe dementia is associated with patient comfort and functional status that are as good as, or better than, those associated with tube feeding. In addition, older adults with advanced dementia who are handfed run lower risks of both aspiration pneumonia and mortality than those with percutaneous feeding tubes. Tube feeding is associated with agitation, increased use of physical and chemical restraints, and worsening pressure ulcers as well.

Patients with advanced dementia frequently develop eating and swallowing difficulties that lead to reduced oral intake, weight loss, and aspiration. Approximately one-third of nursing home residents with advanced dementia have a feeding tubes. ${ }^{7}$ Feeding tube use is intended to prevent serious adverse outcomes such as aspiration pneumonia, consequences of malnutrition, functional decline, and death, and to improve patient comfort. Yet tube feeding cannot be expected to prevent aspiration of oral secretions or to reduce risk of regurgitation; and no published studies have suggested that feeding tube insertion can reduce the risk of aspiration pneumonia. ${ }^{8}$ In fact, a nonrandomized study found that orally fed patients with oropharyngeal dysphagia had significantly fewer major aspiration events than those fed by tube. ${ }^{9}$ Regarding under-nutrition, no data suggest that providing additional nutrients via feeding tube improves meaningful clinical outcomes. ${ }^{8,10}$ A Cochrane systematic review notes that the use of feeding tubes among patients with advanced dementia is not associated with improved nutritional status, lower risks of pressure ulcers, or longer survival ${ }^{11}$ when compared with hand-feeding. Yet another comprehensive review found no data to suggest that tube feeding can improve pressure ulcer outcomes, reduce infections, enhance

J Am Geriatr Soc. Author manuscript; available in PMC 2014 April 01. 
functional status, or increase patient comfort. ${ }^{8}$ In fact, a propensity analysis found that tube feeding was significantly associated with worse pressure sore outcomes. ${ }^{12}$

The adverse, burdensome effects of tube feeding are significant. Aspiration pneumonia is the most common adverse event. ${ }^{13}$ Others include tube occlusion, leaking, and local infection. ${ }^{8}$ Further, patients may need to be physically or chemically restrained. ${ }^{14}$ to keep them from pulling the feeding tube out of place.

Conservative hand feeding approaches begin with appropriately positioning the patient -with the upright position preferred ${ }^{15}$ when possible. Other factors that appear to improve outcomes with hand feeding include nursing home staff education, ad lib diets, medication adjustments [16], and use of finger foods, preferred foods ${ }^{17}$, and foods with strong flavors. ${ }^{18}$ Specific feeding ${ }^{15}$ techniques -- such as offering frequent reminders to swallow multiple times per bolus ${ }^{17}$ and reducing bolus size to smaller than one teaspoon 18 ; encouraging gentle coughs after each swallow ${ }^{18}$; using facilitating techniques such as stroking the cheeks and neck ${ }^{19}$; placing food and fluid well into the mouth ${ }^{19}$; and optimizing the eating environment -- all seem reasonable as well, though an evidence base for these strategies is not well-established.

There are significant opportunities to improve decision- making on behalf of patients with advanced dementia and feeding difficulties. In a study of relatives of residents with dementia who died in nursing homes and had had a feeding tube, $13.7 \%$ reported that there was no prior discussion about feeding tube insertion. In cases in which such discussions did occur, $41.6 \%$ of relatives reported that the discussion lasted fewer than 15 minutes, and $12.6 \%$ reported feeling pressured by the physician to insert the tube. Tellingly, family members with loved ones who died with a feeding tube were less likely to report that their relatives received excellent end-of-life care than those who did not ${ }^{20}$.

Approaches to address this issue have been developed and tested. A randomized controlled trial has found that a decision aid for surrogates deciding among feeding options for nursing home residents with advanced dementia improved the quality of decision-making. This intervention showed evidence of sustained benefit over time. ${ }^{21}$

\section{Don't use antipsychotics as first choice to treat behavioral and} psychological symptoms of dementia-Older adults with dementia frequently exhibit aggression, resistance to care, and other disruptive or challenging behaviors. While antipsychotics are often prescribed in such cases, these medications provide limited benefits and can increase risks of serious harm, including stroke and premature death. Use of these drugs should be limited among this population.

The recommendation to avoid using antipsychotics as first-choice treatments for behavioral and psychological symptoms of dementia is based both on evidence from randomized controlled trials and on expert opinion., 22, 23 Findings have shown that these medications are not generally effective for these patients.

In a 42-site, double-blind, placebo-controlled trial, 421 outpatients with Alzheimer's disease and psychosis, aggression, or agitation were randomly prescribed one of three atypical antipsychotic medications (olanzapine, quetiapine, risperidone) or placebo and followed for as many as 36 weeks. There were no differences among these groups with regard to improvement on the Clinical Global Impression of Change scale. In addition, there were no differences among groups with regard to time to discontinuation of treatment. The adverse effects accompanying the medications offset any benefits of treatment for psychosis, aggression, or agitation in these patients. ${ }^{22}$ 
Given this and other studies that have come to similar conclusions, experts have been investigating alternatives for managing aggression, resistance to care, and other challenging behaviors in patients with dementia. Both the AGS' 2012 Beers Criteria Update Expert Panel $^{2}$ and the National Institute for Health and Clinical Excellence and Social Care Institute for Excellence (NICE-SCIE) have concluded that behaviors associated with dementia should be managed by non-pharmacological means in most circumstances. ${ }^{23}$

Identifying and addressing causes of such behavior may obviate drug treatment that is directed at these behaviors. Use of antipsychotic drugs should be limited to cases in which non-pharmacologic measures have failed and "there is severe distress or an immediate risk of harm to the person with dementia or others," and when doing so is important to assess and care-plan for expected effect. ${ }^{24}$

\section{Avoid using medication to achieve hemoglobin A1c $<7.5 \%$ in most older} adults; moderate control is generally better-Although older adults make up a large and growing group of those with diabetes, trials of glycemic control have generally focused on middle-aged adults with the disease. In 2012, 26.9 percent of United States residents 65 years old or older had diabetes. ${ }^{24}$ The prevalence of diabetes among Americans older than 65 increased $62 \%$ from 1994 to $2004,{ }^{25}$ and studies suggest that the largest increases in the diabetic population will continue to be among older adults. ${ }^{26,27}$ Despite this, a recent Cochrane systematic review found that only four of 20 trials included subjects with a mean age over 65 , and that only two of these four studies enrolled more than 100 participants. ${ }^{28}$

With sparse evidence for appropriate glycemic targets for older adults, the A1c $<7.0 \%$ target for middle-aged adults has become the default glycemic target for older people in many settings. Yet this target is inappropriate for older patients both because they risk greater harm with intensive control than do younger adults, and because the potential benefits of intensive control are less likely among older adults than among younger ones.

The benefits of glycemic control were studied in four large randomized trials: UK Prospective Diabetes Study (UKPDS), Action to Control Cardiovascular Risk in Diabetes (ACCORD) trial, Action in Diabetes and Vascular Disease: Preterax and Diamicron Modified Release Controlled Evaluation (ADVANCE) and the VA Diabetes Trial. Results from UKPDS suggest that, among newly-diagnosed, middle-aged adults with diabetes (mean age 53), more intensive glycemic control decreases the incidence of vascular complications. In the study, more intensive glycemic control (Hemoglobin A1c 7.0 vs $7.9 \%$ ) with Metformin ${ }^{29}$ led to decreases in myocardial infarction and all-cause mortality at 10 years. More intensive control with sulfonylureas or insulin led to decreases in myocardial infarction at 16 years, and all-cause mortality at 19 years. ${ }^{30}$ The magnitude of benefit was greater for Metformin, with hazard ratios of $0.6-0.7$ for intensive glycemic control, compared to hazard ratios of $0.8-0.9$ for sulfonylureas/insulin. ${ }^{30}$ Older adults, however, are less likely to realize the benefits of intensive control than younger patients for a number of reasons. First, older adults with diabetes are less likely to be newly diagnosed, ${ }^{27}$ and patients with established diabetes are less likely to benefit from more intensive control. ${ }^{31}$ Second, it takes ten to19 years before the benefits of more intensive glycemic control are seen. In addition, many older adults with diabetes have numerous comorbidities that may result in limited life expectancy. Consequently, it is unlikely that these older adults will survive to benefit from the decreased vascular complications that intensive glycemic control can afford. ${ }^{32}$

The industry-sponsored Action in Diabetes and Vascular Disease: Preterax and Diamicron Modified Release Controlled Evaluation (ADVANCE) focused on older adults (mean age 66) with established diabetes. At five years, the study found that intensive control (HbA1c 
$6.5 \%$ vs $7.3 \%$ ) with the sulfonylurea gliclazide led to decreases in macroalbuminuria ( $2.9 \%$ vs $4.1 \%$ ). There were, however, no differences in rates of myocardial infarction, major cardiovascular events, retinopathy, neuropathy, or all-cause mortality. ${ }^{33}$ In observational studies, macroalbuminuria has been associated with accelerated decline in renal function $\left(1.7 \mathrm{~mL} / \mathrm{min}\right.$ eGFR loss per year) ${ }^{34}$ and this suggests that, for most patients, it would take more than 10 years for macroalbuminuria to lead to end stage renal disease. For many older adults with diabetes who have limited life expectancy, then, it is unlikely they will survive to benefit from the decreased rates of end-stage renal disease.

The two other large trials of glycemic control have also found no improvement in outcomes with intensive glycemic control. In the Action to Control Cardiovascular Risk in Diabetes (ACCORD) trial (mean age 62), intensive glycemic control (HbA1c 6.5\% vs $7.5 \%$ ) resulted in no difference in the primary outcome of nonfatal myocardial infarction, nonfatal stroke, or cardiovascular mortality. ${ }^{35}$ (Increased mortality is discussed below). In the VA Diabetes Trial (mean age 60), intensive glycemic control (HbA1c 6.9\% vs $8.1 \%$ ) resulted in decreased rates of progression of nephropathy, but with no differences in major cardiovascular outcomes or all-cause mortality. ${ }^{36}$

Taken together, these trials suggest that the benefits of more intensive glycemic control are greatest for patients with newly-diagnosed disease. Although decreases in surrogate outcomes such as albuminuria occur within five years, it takes 10 to 19 years for decreases in clinical outcomes, such as mortality, to be seen.

The four large randomized trials revealed two major potential harms of more intensive glycemic control: hypoglycemia and increased mortality. Nearly all studies of glycemic control suggest that more intensive control leads to more hypoglycemia and more severe hypoglycemia. In the ADVANCE study, for example, severe hypoglycemia (defined as hypoglycemia requiring the help of another person) was noted in $2.7 \%$ of the intensive control group, compared to $1.5 \%$ of the standard control group -- contributing to an increase in hospitalizations in the intensive control group. In ACCORD, the prevalence of hypoglycemia requiring medical assistance was $10.5 \%$ in the intensive control group, compared to $3.5 \%$ in the standard control group.

Observational studies suggest that older adults may be at particularly high risk of hypoglycemia. Age, polypharmacy, and hospitalization have been implicated in increasing the risk of hypoglycemia ${ }^{37}$ and each of these risk factors is more prevalent among older adults. Thus, the risk of hypoglycemia with intensive glycemic control in older adults will likely be higher than in studies of intensive glycemic control in middle-aged adults.

In addition, there is some evidence suggesting that more intensive glycemic control leads to increased all-cause mortality. In 2008, the ACCORD study was terminated early due to an unexpected increase in all-cause mortality (5.0\% in intensive control vs $4.0 \%$ in standard control, $\mathrm{p}=0.04)$. To date, the underlying cause of the increased mortality in the intensive control group is unclear. ${ }^{38}$ However, this, combined with the results of the University Group Diabetes Program -- which showed increased mortality with the sulfonylurea Tolbutamide ${ }^{39}$-- the ACCORD mortality results suggest there may be mortality risks associated with more intensive glycemic control.

Taken together, there is strong evidence to suggest that more intensive glycemic control will lead to more hypoglycemia, and that hypoglycemia risk increases with age, comorbidity burden, and polypharmacy. Intensive glycemic control has also been found to lead to increased mortality, although the mechanism of this link is currently unclear. 
In summary, the evidence base suggests that, compared to middle-aged adults, older adults are more likely to be harmed by intensive glycemic control and less likely to benefit from it. Reviewing this evidence base, several expert panels have come to the conclusion that glycemic targets for older adults should be individualized. ${ }^{31,40,41} \mathrm{We}$ absolutely agree.

For older patients with newly-diagnosed disease, little comorbidity, extended life expectancy, and few established vascular complications, intensive control to HbA1c of 7.0\% is appropriate. However, relatively few patients older than 65 meet those criteria. Studies suggest that $59 \%$ of older patients with diabetes developed it prior to age $65^{34}$ and therefore are not "newly diagnosed." Further, many older adults have substantial comorbidities and limited life expectancy. In a nationally-representative sample of older adults over 65 with diabetes living in the US, $39 \%$ had three or more chronic conditions (in addition to diabetes), cognitive impairment, severe visual impairment, or difficulty in two instrumental activities of daily living. ${ }^{42}$ Moreover, 57 percent of Americans over 65 with diabetes have serious comorbidities or geriatric syndromes such as heart failure or falls. ${ }^{43}$ Thus, for the large majority of adults over age 65 with diabetes of longstanding duration, comorbidity burden, and limited life expectancy less intensive glycemic control (avoiding using medicines to achieve $\mathrm{HbA} 1 \mathrm{c}<7.5 \%$ ) is most appropriate. In light of this, we recommend the following:

- For healthy older adults with few comorbidities and life expectancy $>10$ years with newly diagnosed diabetes, a reasonable $\mathrm{HbA1c}$ target would be $7.0-7.5 \%$

- For older adults with moderate comorbidities and life expectancy between $5-10$ years, a reasonable $\mathrm{HbA1c}$ target would be $7.5-8.0 \%$.

- For older adults with multiple comorbidities, functional or cognitive impairments and life expectancy $<5$ years (including the vast majority of nursing home residents), a reasonable $\mathrm{HbA} 1 \mathrm{c}$ target would be $8.0-9.0 \%$.

Because the evidence for benefit is strongest for metformin and the risk of hypoglycemia is lower with this medication, it should be the drug of choice for glycemic control unless contraindicated.

\section{Don't use benzodiazepines or other sedative-hypnotics in older adults as first choice for insomnia, agitation or delirium-Insomnia, agitation, and delirium} are very common in older adults, and medications to treat these conditions are frequently used by older Americans. ${ }^{44,45,46}$

Extensive evidence, however, suggests that benzodiazepines and other sedative-hypnotic medications (including the newer "Z-compounds" -- zolpidem, eszopiclone and zaleplon) more than double risks of both falls and hip fractures leading to hospitalization and death among older patients. Given the risks, these medications should be used sparingly with older adults.

Both short-term randomized trials and long-term epidemiologic studies provide evidence of the risks these medications pose. Stenbacka and colleagues found that Swedish women who used hypnotics and sedatives daily from 1984 to 1997 ran nearly double the risk of injurious falls leading to hospitalization and death (relative risk 1.83 ; 95\% CI 1.10, 3.06). ${ }^{47}$ In a study of community-dwelling adults 65 and older, Finkle found that benzodiazepines and zolpidem significantly increased risks of non-vertebral fractures and hip fractures. ${ }^{48}$ After adjusting for confounders, the risk ratio for hip fractures after initiating zolpidem compared with the risk before administration of the medication, was 3.11 (95\% CI 1.96, 4.91). This risk was similar to that of diazepam, suggesting that zolpidem is not a safer alternative. 
Among older adults, benzodiazepines have also been implicated in diminished cognition, delirium, and motor vehicle accidents. A recent meta-analysis of randomized, controlled, short-term trials (most of these lasting five to 28 nights) enrolling older adults suggests that memory problems, disorientation, confusion, and other adverse cognitive effects are more common with benzodiazepines and newer Z-compounds than placebo (Odds ratio 4.78, 95\% CI: 1.47, 15.5). (16284208). ${ }^{49}$ In addition, a case-control study of surgical patients (mean age $73 \pm 8$ years) found that postoperative exposure to benzodiazepines was also strongly associated with development of delirium (OR 3.0; 95\% CI 1.3, 6.8). ${ }^{50}$ Finally, a metaanalysis of cohort studies by Rapoport found that risks of motor vehicle accidents were higher (odds ratio $1.60,95 \%$ CI: $1.29,1.97$ ) in adults taking benzodiazepines. ${ }^{51}$

The recently revised 2012 American Geriatrics Society Updated Beers Criteria for Potentially Inappropriate Medication Use in Older Adults, notes that older adults should avoid benzodiazepines because they increase not only risks of falls, fractures, motor vehicle accidents, and delirium, but also risks of cognitive impairment. The criteria further note that non-benzodiazepine hypnotics should not be prescribed for chronic use due to evidence of similar adverse events and limited effectiveness in improving sleep latency and duration. ${ }^{2}$

Given these findings, benzodiazepines and newer Z-compounds should be used sparingly among older patients, and only after other interventions have been tried and failed.

\section{Don't use antimicrobials to treat bacteriuria in older adults unless specific urinary tract symptoms are present-Cohort studies have found no adverse outcomes for older men or women who have asymptomatic bacteriuria (ASB) but do not get antimicrobial treatments for this. In fact, antimicrobial treatment of ASB may result in adverse antimicrobial effects.}

ASB is a common occurrence in older adults and its prevalence increases with age. In community populations of women aged 65 to 90 , the prevalence of ASB ranges from $6 \%$ to $16 \%$. Prevalence is highest in women over age 90 , among whom it ranges from $22 \%$ to $43 \%$. In community populations of men older than 65, prevalence of ASB ranges from 5\% to $21 \%$ and the highest prevalence is also among those older than 90 . Among the institutionalized elderly, $25 \%$ to $50 \%$ of women and $15 \%$ to $35 \%$ of men have ASB. ${ }^{52}$

The clinical importance of ASB has been controversial since the widespread use of the quantitative urine culture first provided a reliable means of identification in the 1950s. ${ }^{53}$ Antimicrobial therapy for ASB has no short-term or long-term benefits, in men or women, on mortality, genitourinary symptoms (including incontinence), or risk for subsequent symptomatic episodes. In fact, antimicrobial therapy for ASB has been associated with such negative outcomes as adverse drug reactions and re-infection with more resistant organisms. ${ }^{54,55}$ In community populations, individuals with bacteriuria are at increased risk of symptomatic infection -- but this is not attributable to bacteriuria.

Identifying cases of symptomatic urinary tract infection (UTI) in frail or cognitivelyimpaired elderly is often challenging. Multiple comorbid illnesses may present with symptoms similar to those of UTI and the acute worsening of a preexisting problem is a common reason to suspect UTI. ${ }^{52,56}$ The Society of Healthcare Epidemiology of America has published proposed criteria for both the initiation of antibiotics for symptomatic UTI ${ }^{57}$ and surveillance definitions for UTI in nursing home populations. ${ }^{58,59}$ These criteria take into account the low probability of a UTI in elderly patients without indwelling catheters if localizing symptoms are not present, as well as the need for microbiologic confirmation for the diagnosis. 
Older patients with ASB who undergo traumatic genitourinary procedures associated with mucosal bleeding have a high rate of post-procedure bacteremia and sepsis, and clinical evidence supports the effectiveness of antimicrobial treatment in preventing these complications in men undergoing transurethral resection of the prostate. There is little information relevant to other interventions, but screening for and treatment of asymptomatic bacteriuria is recommended before urologic procedures for which mucosal bleeding is anticipated. ${ }^{60}$

\section{CONCLUSION}

With the eldest of the nation's 77 million Baby Boomers already 65, and the youngest reaching that milestone in 2019, older adults will make up a growing share of the nation's population for the next four decades. Now roughly 40 million, the number of U.S. residents 65 and older will reach an estimated 78.9 million in 2050.61

Currently, 80 percent of adults 65 and older have at least one chronic health condition 62 and roughly half have three or more. In light of this, it is likely that the number of older adults undergoing tests and treatments for healthcare problems will increase significantly over time.

Yet, the evidence base supporting the use of many common tests and treatments for older adults is inadequate, in part because older patients are significantly underrepresented in clinical trials. Clearly, filling gaps in the evidence base is essential. But given the prevalence of multimorbidity among older patients, this will be a complex and time consuming undertaking. In the meantime, it is particularly important that patients and their healthcare providers follow the suggestion of the ABIM and discuss what is, and is not, known about the potential benefits and risks of common tests and treatments. This way, these patients can truly choose wisely.

\section{REFERENCES}

1. Department of Health and Human Services Administration on Aging. [Accessed November 18, 2012] A Profile of Older Americans: 2011 (on-line). Available at http://www.aoa.gov/AoARoot/ Aging_Statistics/Profile/index.aspx

2. The American Geriatrics Society 2012 Beers Criteria Update Expert Panel. American Geriatrics Society updated Beers criteria for potentially inappropriate medication use in older adults. Journal of the American Geriatrics Society. 2012; 60:616-631. [PubMed: 22376048]

3. American Geriatrics Society Expert Panel on the Care of Older Adults with Multimorbidity. Guiding principles for the care of older adults with multimorbidity: An approach for clinicians. J Am Geriatr Soc. 2012; 60:E1-E25. [PubMed: 22994865]

4. Boyd CM, Darer J, Boult C, et al. Clinical practice guidelines and quality of care for older patients with multiple comorbid diseases: Implications for pay for performance. JAMA. 2005; 294:716-724. [PubMed: 16091574]

5. Berwick DM, Hackbarth AD. Eliminating waste in US health care. JAMA. 2012; 307:1513-1516. [PubMed: 22419800]

6. Congressional Budget Office. [Accessed November 20, 2012] Increasing the value of federal spending on health care, testimony before the Committee on the Budget, US House of Representatives. Jul 16. 2008 Available at www.cbo.gov/publication/41717

7. Mitchell SL, Teno JM, Roy J, et al. Clinical and organizational factors associated with feeding tube use among nursing home residents with advanced cognitive impairment. JAMA. 2003; 290:73-80. [PubMed: 12837714]

8. Finucane TE, Christmas C, Travis K. Tube feeding in patients with advanced dementia: A review of the evidence. JAMA. 1999; 282:1365-1370. [PubMed: 10527184] 
9. Feinberg MJ, Knebl J, Tully J. Prandial aspiration and pneumonia in an elderly population followed over 3 years. Dysphagia. 1996; 11:104-109. [PubMed: 8721068]

10. Dharmarajan TS, Unnikrishnan D, Pitchumoni CS. Percutaneous endoscopic gastrostomy and outcome in dementia. Am J Gastroenterol. 2001; 96:2556-2563. [PubMed: 11569675]

11. Sampson EL, Candy B, Jones L. Enteral tube feeding for older people with advanced dementia. Cochrane Database Systematic Reviews. 2009; 2

12. Teno JM, Gozalo P, Mitchell SL, et al. Feeding tubes and the prevention or healing of pressure ulcers. Intern Med. 2012; 172:697-701.

13. Finucane TE, Bynum JP. Use of tube feeding to prevent aspiration pneumonia. Lancet. 1996; 348:1421-1424. [PubMed: 8937283]

14. Quill TE. Utilization of nasogastric feeding tubes in a group of chronically ill, elderly patients in a community hospital. Arch Intern Med. 1989; 149:1937-1941. [PubMed: 2505703]

15. DiBartolo MC. Careful hand feeding: A reasonable alternative to PEG tube placement in individuals with dementia. J Gerontol Nurs. 2006; 32:25-33. [PubMed: 16708981]

16. Abbasi AA, Rudman D. Undernutrition in the nursing home: Prevalence, consequences, causes and prevention. Nutr Rev. 1994; 52:113-122. [PubMed: 8028816]

17. Morley JE. Dementia is not necessarily a cause of undernutrition. J Am Geriatr Soc. 1996; 44:1403-1404. [PubMed: 8909363]

18. Horner J, Massey EW, Riski JE, et al. Aspiration following stroke: Clinical correlates and outcome. Neurology. 1988; 38:1359-1362. [PubMed: 3412582]

19. Scott AG, Austin HE. Nasogastric feeding in the management of severe dysphagia in motor neuron disease. Palliat Med. 1994; 8:45-49. [PubMed: 8180740]

20. Teno JM, Mitchell SL, Kuo SK, et al. Decision-making and outcomes of feeding tube insertion: A five-state study. J Am Geriatr Soc. 2011; 59:881-886. [PubMed: 21539524]

21. Hanson LC, Carey TS, Caprio AJ, et al. Improving decision-making for feeding options in advanced dementia: A randomized, controlled trial. J Am Geriatr Soc. 2011; 59:2009-2016. [PubMed: 22091750]

22. Schneider LS, Tariot PN, Dagerman KS, et al. CATIE-AD Study Group. Effectiveness of atypical antipsychotic drugs in patients with Alzheimer's disease. N Engl J Med. 2006; 355:1525-1538. [PubMed: 17035647]

23. National Institute for Health and Clinical Excellence. [Accessed on September 5, 2012] Dementia interventions. (on-line) Available at http://www.nlm.nih.gov/bsd/uniform_requirements.html

24. Department of Health and Human Services Center for Disease Control and Prevention. National Diabetes Fact Sheet: national estimates and general information on diabetes and prediabetes in the United States. 2011.

25. Sloan FA, Bethel MA, Ruiz D Jr. et al. The growing burden of diabetes mellitus in the US elderly population. Arch Intern Med. 2008; 168:192-199. [PubMed: 18227367]

26. Boyle JP, Honeycutt AA, Narayan KM, et al. Projection of diabetes burden through 2050: Impact of changing demography and disease prevalence in the U.S. Diabetes Care. 2001; 24:1936-1940. [PubMed: 11679460]

27. Selvin E, Coresh J, Brancati FL. The burden and treatment of diabetes in elderly individuals in the U.S. Diabetes Care. 2006; 29:2415-2419. [PubMed: 17065677]

28. Hemmingsen B, Lund SS, Gluud C, et al. Targeting intensive glycaemic control versus targeting conventional glycaemic control for type 2 diabetes mellitus. Cochrane Database Syst Rev. 2011; 6

29. UK Prospective Diabetes Study Group. Effect of intensive blood-glucose control with metformin on complications in overweight patients with type 2 diabetes. Lancet. 1998; 352:854-865. [PubMed: 9742977]

30. Holman RR, Paul SK, Bethel MA, et al. Long-term follow-up after tight control of blood pressure in type 2 diabetes. N Engl J Med. 2008; 359:1565-1576. [PubMed: 18784091]

31. Department of Veterans Affairs and Department of Defense. [Accessed January 9, 2013] Clinical practice guideline for the management of diabetes mellitus (on-line). Available at http:// guidelines.gov/content.aspx $? \mathrm{id}=24192$ 
32. Lee SJ, Eng C. Goals of glycemic control in frail older patients with diabetes. JAMA. 2011; 305:1350-1351. [PubMed: 21467289]

33. Patel A, MacMahon S, Chalmers J, et al. Intensive blood glucose control and vascular outcomes in patients with type 2 diabetes. N Engl J Med. 2008; 358:2560-2572. [PubMed: 18539916]

34. Halbesma N, Kuiken DS, Brantsma AH, et al. Macroalbuminuria is a better risk marker than low estimated GFR to identify individuals at risk for accelerated GFR loss in population screening. J Am Soc Nephrol. 2006; 17:2582-2590. [PubMed: 16899519]

35. Gerstein HC, Miller ME, Byington RP, et al. Effects of intensive glucose lowering in type 2 diabetes. N Engl J Med. 2008; 358:2545-2559. [PubMed: 18539917]

36. Duckworth W, Abraira C, Moritz T, et al. Glucose control and vascular complications in veterans with type 2 diabetes. N Engl J Med. 2009; 360:129-139. [PubMed: 19092145]

37. Shorr RI, Ray WA, Daugherty JR, et al. Incidence and risk factors for serious hypoglycemia in older persons using insulin or sulfonylureas. Arch Intern Med. 1997; 157:1681-1686. [PubMed: 9250229]

38. Bonds DE, Miller ME, Bergenstal RM, et al. The association between symptomatic, severe hypoglycaemia and mortality in type 2 diabetes: retrospective epidemiological analysis of the ACCORD study. BMJ. 2010; 340:b4909. [PubMed: 20061358]

39. Meinert CL, Knatterud GL, Prout TE, et al. A study of the effects of hypoglycemic agents on vascular complications in patients with adult-onset diabetes. II. Mortality results. Diabetes. 1970; 19(Suppl):789-830. [PubMed: 4926376]

40. Inzucchi SE, Bergenstal RM, Buse JB, et al. Management of hyperglycemia in type 2 diabetes: a patient-centered approach: Position statement of the American Diabetes Association (ADA) and the European Association for the Study of Diabetes (EASD). Diabetes Care. 2012; 35:1364-1379. [PubMed: 22517736]

41. Sinclair A, Morley JE, Rodriguez-Manas L, et al. Diabetes mellitus in older people: position statement on behalf of the International Association of Gerontology and Geriatrics (IAGG), the European Diabetes Working Party for Older People (EDWPOP), and the International Task Force of Experts in Diabetes. J Am Med Dir Assoc. 2012; 13:497-502. [PubMed: 22748719]

42. Blaum C, Cigolle CT, Boyd C, et al. Clinical complexity in middle-aged and older adults with diabetes: The Health and Retirement Study. Med Care. 2010; 48:327-334. [PubMed: 20355264]

43. Lee PG, Cigolle C, Blaum C. The co-occurrence of chronic diseases and geriatric syndromes: The health and retirement study. J Am Geriatr Soc. 2009; 57:511-516. [PubMed: 19187416]

44. Foley DJ, Monjan AA, Brown SL, et al. Sleep complaints among elderly persons: An epidemiologic study of three communities. Sleep. 1995; 18:425-32. [PubMed: 7481413]

45. Bolge SC, Doan JF, Kannan H, et al. Association of insomnia with quality of life, work productivity, and activity impairment. Qual Life Res. 2009; 18:415-422. [PubMed: 19288223]

46. Bartholow, M. [Accessed September 5, 2012] Top 200 Drugs of 2010 (on-line). Available at http:// www.pharmacytimes.com/publications/issue/2011/May2011/Top-200-Drugs-of-2010

47. Stenbacka M, Jansson B, Leifman A, et al. Association between use of sedatives or hypnotics, alcohol consumptions, or other risk factors and a single injurious fall or multiple injurious falls: A longitudinal general population study. Alcohol. 2002; 28:9-16. [PubMed: 12377356]

48. Finkle WD, Der JS, Greenland S, et al. Risk of fractures requiring hospitalization after an initial prescription for zolpidem, alprazolam, lorazepam, or diazepam in older adults. J Am Ger Soc. 2011; 59:1883-1890.

49. Glass J, Lanctôt KL, Herrmann N, et al. Sedative hypnotics in older people with insomnia: Metaanalysis of risks and benefits. BMJ. 2005; 331:1169. [PubMed: 16284208]

50. Marcantonio ER, Juarez G, Goldman L, et al. The relationship of postoperative delirium with psychoactive medications. JAMA. 1994; 272:1518-1522. [PubMed: 7966844]

51. Rapoport MJ, Lanctôt KL, Streiner DL, et al. Benzodiazepine use and driving: A meta-analysis. J Clin Psychiatry. 2009; 70:663-673. [PubMed: 19389334]

52. Juthani-Mehta M. Asymptomatic bacteriuria and urinary tract infection in older adults. Clin Geriatr Med. 2007; 23:585-594. [PubMed: 17631235]

53. Nicolle LE. Asymptomatic bacteriuria: when to screen and when to treat. Infect Dis Clin N Am. $2003 ; 17: 367-394$. 
54. Nicolle LE, Bjornson J, Harding GK, et al. Bacteriuria in elderly institutionalized men. N Engl J Med. 1983; 309:731-735.

55. Nicolle LE, Mayhew WJ, Bryan L. Prospective randomized comparison of therapy and no therapy for asymptomatic bacteriuria in institutionalized elderly women. Am J Med. 1987; 83:27-33. [PubMed: 3300325]

56. Woodford HJ, George J. Diagnosis and management of urinary tract infection in hospitalized older people. JAGS. 2009; 57:107-114.

57. Loeb M, Bentley DW, Bradley S, et al. Development of minimum criteria for the initiation of antibiotics in residents of long-term-care facilities: the results of a consensus conference. Infect Control Hosp Epidemiol. 2001; 22:120-124. [PubMed: 11232875]

58. McGeer A, Campbell B, Emori TG, et al. Definitions of infection for surveillance in long-term care facilities. Am J Infect Control. 1991; 19:1-7. [PubMed: 1902352]

59. Stone NM, Ashraf MS, Calder J, et al. Surveillance definitions of infections in long-term care facilities: revisiting the McGeer Criteria. Infect Control Hosp Epidemiol. 2012; 22:965-977. [PubMed: 22961014]

60. Nicolle LE, Bradley S, Colgan R, et al. Infectious Diseases Society of America Guidelines for the Diagnosis and Treatment of Asymptomatic Bacteriuria in Adults. Clin Infect Dis. 2005; 40:643665. [PubMed: 15714408]

61. US Department of Commerce Economics and Statistics Administration Bureau of the Census. [Accessed on November 30, 2012] Aging in the United States - Past President and Future (online). Available at http://www.census.gov/population/international/files/97agewc.pdf

62. US Department of Health and Human Services Center for Disease Control and Prevention. [Accessed on November 30, 2012] Healthy aging: Improving and extending quality of life among older Americans 2009 (online). Available at http://www.cdc.gov/nccdphp/publications/aag/pdf/ healthy_aging.pdf 
TABLE

“TOP FIVE LIST" IN GERIATRICS

\begin{tabular}{|c|c|c|}
\hline \multicolumn{3}{|c|}{$\begin{array}{l}\text { AGS Choosing Wisely } \\
\text { Five Things Physicians and Patients Should Question }\end{array}$} \\
\hline Recommendation & Rationale & Citations \\
\hline $\begin{array}{l}\text { Don't recommend } \\
\text { percutaneous feeding } \\
\text { tubes in patients with } \\
\text { advanced dementia; } \\
\text { instead offer oral } \\
\text { assisted feeding. }\end{array}$ & $\begin{array}{l}\text { Careful hand-feeding for } \\
\text { patients with severe dementia } \\
\text { is at least as good as tube- } \\
\text { feeding for the outcomes of } \\
\text { death, aspiration pneumonia, } \\
\text { functional status and patient } \\
\text { comfort. Food is the preferred } \\
\text { nutrient. Tube-feeding is } \\
\text { associated with agitation, } \\
\text { increased use of physical and } \\
\text { chemical restraints and } \\
\text { worsening pressure ulcers. }\end{array}$ & $\begin{array}{l}\text { Finucane TE, Christmas C, Travis K. Tube } \\
\text { feeding in patients with advanced } \\
\text { dementia: A review of the evidence. JAMA. } \\
\text { 1999;282(14):1365-1370. } \\
\text { Gabriel SE, Normand ST. Getting the } \\
\text { methods right - The foundation of patient- } \\
\text { centered outcomes research. N Engl J Med } \\
\text { [Internet]. 2012 Aug 30;367(9):787-90. } \\
\text { Teno JM, Feng Z, Mitchell SL, Kuo S, Intrator } \\
\text { O, Mor V. Do financial incentives of } \\
\text { introducing case mix reimbursement } \\
\text { increase feeding tube use in nursing home } \\
\text { residents? J Am Geriatr Soc. [Internet]. } \\
\text { 2008 May;56(5):887-890. } \\
\text { Teno JM, Mitchell SL, Kuo SK, Gozalo PL, } \\
\text { Rhodes RL, Lima JC, Mor V. Decision- } \\
\text { making and outcomes of feeding tube } \\
\text { insertion: A five-state study. J Am Geriatr } \\
\text { Soc.[Internet]. 2011 May;59(5):881-886. } \\
\text { Palecek EJ, Teno JM, Casarett DJ, Hanson } \\
\text { LC, Rhodes RL, Mitchell SL. Comfort feeding } \\
\text { only: A proposal to bring clarity to decision- } \\
\text { making regarding difficulty with eating for } \\
\text { persons with advanced dementia. J Am } \\
\text { Geriatr Soc. [Internet]. 2010 } \\
\text { Mar;58(3):580-584. } \\
\text { Hanson LC, Carey TS, Caprio AJ, Lee TJ, } \\
\text { Ersek M, Garrett J, Jackman A, Gilliam R, } \\
\text { Wessell K, Mitchell SL. Improving decision- } \\
\text { making for feeding options in advanced } \\
\text { dementia: A randomized, controlled trial. J } \\
\text { Am Geriatr Soc. [Internet]. 2011 } \\
\text { Nov;59(11):2009-2016. }\end{array}$ \\
\hline $\begin{array}{l}\text { Don't use antipsychotics } \\
\text { as first choice to treat } \\
\text { behavioral and } \\
\text { psychological symptoms } \\
\text { of dementia. }\end{array}$ & $\begin{array}{l}\text { People with dementia often } \\
\text { exhibit aggression, resistance } \\
\text { to care and other challenging } \\
\text { or disruptive behaviors. In } \\
\text { such instances, antipsychotic } \\
\text { medicines are often } \\
\text { prescribed, but they provide } \\
\text { limited benefit and can cause } \\
\text { serious harm, including stroke } \\
\text { and premature death. Use of } \\
\text { these drugs should be limited } \\
\text { to cases where non- } \\
\text { pharmacologic measures have } \\
\text { failed and patients pose an } \\
\text { imminent threat to } \\
\text { themselves or others. } \\
\text { Identifying and addressing } \\
\text { causes of behavior change can } \\
\text { make drug treatment } \\
\text { unnecessary. }\end{array}$ & $\begin{array}{l}\text { The American Geriatrics Society } 2012 \text { Beers } \\
\text { Criteria Update Expert Panel. American } \\
\text { Geriatrics Society Updated Beers Criteria } \\
\text { for potentially inappropriate medication } \\
\text { use in older adults . J Am Geriatr Soc. } 2012 \\
\text { Apr;60(4):616-31. } \\
\text { National Institute for Health and Clinical } \\
\text { Excellence and Social Care Institute for } \\
\text { Excellence NICE-SCIE. National } \\
\text { Collaborating Centre for Mental Health. } \\
\text { Clinical guidelines \#42: Dementia: } \\
\text { Supporting people with dementia and their } \\
\text { careers in health and social care } \\
\text { [Internet]London. 2006 Nov: Amended } \\
\text { 2011 Mar [cited 2012 Oct 16]. Available } \\
\text { from: www.nice.org.uk/CG042 } \\
\text { Maher A, Maglione M, Bagley S, Suttorp M, } \\
\text { Hu JH, Ewing B, Wang Z, Timmer M, Sultzer } \\
\text { D, Shekelle PG. Efficacy and comparative } \\
\text { effectiveness of atypical antipsychotic } \\
\text { medications for off-label uses in adults: A } \\
\text { systematic review and meta-analysis. JAMA } \\
\text { [Internet]. 2011 Sep 28;306(12):1359-69. } \\
\text { Schneider LS, Tariot PN, Dagerman KS, } \\
\text { Davis SM, Hsiao JK, Ismail MS, Lebowitz BD, } \\
\text { Lyketsos CG, Ryan JM, Stroup TS, Sultzer } \\
\text { DL, Weintraub D, Lieberman JA; CATIE-AD } \\
\text { Study Group. } \\
\text { Effectiveness of atypical antipsychotic } \\
\text { drugs in patients with Alzheimer's disease. } \\
\text { N Engl J Med [Internet]. 2006 Oct } \\
\text { 12;355(15):1525-38. }\end{array}$ \\
\hline
\end{tabular}

J Am Geriatr Soc. Author manuscript; available in PMC 2014 April 01. 
AGS Choosing Wisely

Five Things Physicians and Patients Should Question

\begin{tabular}{|c|c|c|}
\hline Recommendation & Rationale & Citations \\
\hline $\begin{array}{l}\text { Avoid using medications } \\
\text { to achieve hemoglobin } \\
\text { Alc }<7.5 \% \text { in most older } \\
\text { adults; moderate control } \\
\text { is generally better. }\end{array}$ & $\begin{array}{l}\text { There is no evidence that } \\
\text { using medications to achieve } \\
\text { tight glycemic control in older } \\
\text { adults with type } 2 \text { diabetes is } \\
\text { beneficial. Among non-older } \\
\text { adults, except for long-term } \\
\text { reductions in myocardial } \\
\text { infarction and mortality with } \\
\text { metformin, using medications } \\
\text { to achieve glycated } \\
\text { hemoglobin levels less than } \\
7 \% \text { is associated with harms, } \\
\text { including higher mortality } \\
\text { rates. Tight control has been } \\
\text { consistently shown to } \\
\text { produce higher rates of } \\
\text { hypoglycemia in older adults. } \\
\text { Given the long timeframe to } \\
\text { achieve theorized } \\
\text { microvascular benefits of tight } \\
\text { control, glycemic targets } \\
\text { should reflect patient goals, } \\
\text { health status, and life } \\
\text { expectancy. Reasonable } \\
\text { glycemic targets would be } 7.0 \\
-7.5 \% \text { in healthy older adults } \\
\text { with long life expectancy, } 7.5- \\
8.0 \% \text { in those with moderate } \\
\text { comorbidity and a life } \\
\text { expectancy < } 10 \text { years, and } 8.0 \\
-9.0 \% \text { in those with multiple } \\
\text { morbidities and shorter life } \\
\text { expectancy. }\end{array}$ & $\begin{array}{l}\text { The Action to Control Cardiovascular Risk in } \\
\text { Diabetes Study Group. Effects of intensive } \\
\text { glucose lowering in Type } 2 \text { Diabetes. N Eng } \\
\text { J Med [Internet]. 2008 Jun } \\
\text { 12;258(24):2545-2559. } \\
\text { The Action to Control Cardiovascular Risk in } \\
\text { Diabetes Study Group. Long-term effects of } \\
\text { intensive glucose lowering on } \\
\text { cardiovascular outcomes. N Eng J Med } \\
\text { [Internet]. 2011Mar 3;364(9):818-828. } \\
\text { Duckworth W, Abraira C, Moritz T, Reda D, } \\
\text { Emanuele N, Reaven P, Zeive FJ, Marks J, } \\
\text { David SN, Hayward R, Warren SR, Goldman } \\
\text { S, McCarren M, Vitek ME, Henderson WG, } \\
\text { Huang GD. Glucose control and vascular } \\
\text { complications in veterans with type } 2 \\
\text { diabetes. N Eng J Med[Internet]. 2009. } \\
\text { 360(2):129-139. } \\
\text { ADVANCE Collaborative Group. Intensive } \\
\text { blood glucose control and vascular } \\
\text { outcomes in patients with type } 2 \text { diabetes. } \\
\text { N Engl J Med[Internet]. 2008 Jun } \\
\text { 12;358:2560-72. } \\
\text { UK Prospective Diabetes Study (UKPDS) } \\
\text { Group. Effect of intensive blood-glucose } \\
\text { control with metformin on complications in } \\
\text { overweight patients with type } 2 \text { diabetes } \\
\text { (UKPDS 34). Lancet [Internet]. } \\
\text { 1998;352:854-65. } \\
\text { Montori VM, Fernández-Balsells M. } \\
\text { Glycemic control in type } 2 \text { diabetes: Time } \\
\text { for an evidence-based about-face? Ann } \\
\text { Intern Med[Internet]. 2009 Jun } \\
\text { 2;150(11):803-8. Erratum in: Ann Intern } \\
\text { Med. 2009 Jul 21;151(2):144. PMID: } \\
\text { 19380837 } \\
\text { Finucane TE. "Tight Control" in geriatrics: } \\
\text { The emperor wears a thong. J Am Geriatr } \\
\text { Soc [Internet]. 2012 Aug 6;60:1571-1575. }\end{array}$ \\
\hline $\begin{array}{l}\text { Don't use } \\
\text { benzodiazepines or } \\
\text { other sedative-hypnotics } \\
\text { in older adults as first } \\
\text { choice for insomnia, } \\
\text { agitation or delirium. }\end{array}$ & $\begin{array}{l}\text { Large scale studies } \\
\text { consistently show that the risk } \\
\text { of motor vehicle accidents, } \\
\text { falls and hip fractures leading } \\
\text { to hospitalization and death } \\
\text { can more than double in older } \\
\text { adults taking benzodiazepines } \\
\text { and other sedative-hypnotics. } \\
\text { Older patients, their } \\
\text { caregivers and their providers } \\
\text { should recognize these } \\
\text { potential harms when } \\
\text { considering treatment } \\
\text { strategies for insomnia, } \\
\text { agitation or delirium. Use of } \\
\text { benzodiazepines should be } \\
\text { reserved for alcohol } \\
\text { withdrawal } \\
\text { symptoms/delirium tremens } \\
\text { or severe generalized anxiety } \\
\text { disorder unresponsive to } \\
\text { other therapies. }\end{array}$ & $\begin{array}{l}\text { Finkle WD, Der JS, Greenland S, Adams JL, } \\
\text { Ridgeway G, Blaschke T, Wang Z, Dell RM, } \\
\text { VanRiper KB. Risk of fractures requiring } \\
\text { hospitalization after an initial prescription } \\
\text { of zolpidem, alprazolam, lorazepam or } \\
\text { diazepam in older adults. J Am Geriatr Soc. } \\
\text { [Internet]. 2011 Oct;59(10):1883-1890. } \\
\text { Allain H, Bentue-Ferrer D, Polard E, Akwa Y, } \\
\text { Patat A. Postural instability and consequent } \\
\text { falls and hip fractures associated with use } \\
\text { of hypnotics in the elderly: a comparative } \\
\text { review. Drugs Aging [Internet]. } \\
\text { 2005;22(9):749-765. } \\
\text { The American Geriatrics Society } 2012 \text { Beers } \\
\text { Criteria Update Expert Panel. American } \\
\text { Geriatrics Society Updated Beers Criteria } \\
\text { for potentially inappropriate medication } \\
\text { use in older adults . J Am Geriatr Soc. } 2012 \\
\text { Apr;60(4):616-31. }\end{array}$ \\
\hline $\begin{array}{l}\text { Don't use antimicrobials } \\
\text { to treat bacteriuria in } \\
\text { older adults unless } \\
\text { specific urinary tract } \\
\text { symptoms are present. }\end{array}$ & $\begin{array}{l}\text { Cohort studies have found no } \\
\text { adverse outcomes for older } \\
\text { men or women associated } \\
\text { with asymptomatic } \\
\text { bacteriuria. Antimicrobial } \\
\text { treatment studies for } \\
\text { asymptomatic bacteriuria in } \\
\text { older adults demonstrate no }\end{array}$ & $\begin{array}{l}\text { Nordenstam GR, Brandberg CA, Odén AS, } \\
\text { Svanborg Edén CM, Svanborg A. Bacteriuria } \\
\text { and mortality in an elderly population. N } \\
\text { Engl J Med. } 1986 \text { May 1;314(18):1152- } \\
1156 . \\
\text { Nicolle LE, Mayhew WJ, Bryan L. } \\
\text { Prospective randomized comparison of } \\
\text { therapy and no therapy for asymptomatic }\end{array}$ \\
\hline
\end{tabular}




\begin{tabular}{|c|c|c|}
\hline \multicolumn{3}{|c|}{$\begin{array}{l}\text { AGS Choosing Wisely } \\
\text { Five Things Physicians and Patients Should Question }\end{array}$} \\
\hline Recommendation & Rationale & Citations \\
\hline & $\begin{array}{l}\text { benefits and show increased } \\
\text { adverse antimicrobial effects. } \\
\text { Consensus criteria has been } \\
\text { developed to characterize the } \\
\text { specific clinical symptoms } \\
\text { that, when associated with } \\
\text { bacteriuria, define urinary } \\
\text { tract infection. Screening for } \\
\text { and treatment of } \\
\text { asymptomatic bacteriuria is } \\
\text { recommended before urologic } \\
\text { procedures for which mucosal } \\
\text { bleeding is anticipated. }\end{array}$ & $\begin{array}{l}\text { bacteriuria in institutionalized elderly } \\
\text { women. Am J Med. 1987Jul;83(1):27-33. } \\
\text { Juthani-Mehta M. Asymptomatic } \\
\text { bacteriuria and urinary tract infection in } \\
\text { older adults. Clin Geriatr Med [Internet]. } \\
2007 \text { Aug;23(3):585-594. } \\
\text { Nicolle LE, Bradley S, Colgan R, Rice JC, } \\
\text { Schaeffer A, Hooton TM; Infectious } \\
\text { Diseases Society of America; American } \\
\text { Society of Nephrology; American Geriatric } \\
\text { Society. Infectious Diseases Society of } \\
\text { America Guidelines for the diagnosis and } \\
\text { treatment of asymptomatic bacteriuria in } \\
\text { adults. Clin Infect Dis. [Internet]. 2005 Mar } \\
\text { 1;40(5):643-65. }\end{array}$ \\
\hline
\end{tabular}

